\title{
Ascertaining Customary International Law: An Inquiry into the Methods Used by Domestic Courts
}

\author{
Cedric M. J. Ryngaert ${ }^{1}$ - Duco W. Hora Siccama ${ }^{2}$
}

\begin{abstract}
Based on analysis of a large number of recent domestic court cases on matters of customary international law (2000-2014), this article demonstrates that, rather similar to the International Court of Justice, domestic courts do not normally identify customary norms of customary international law on the basis of the textbook method of ascertaining a general practice accepted as law. Rather, they tend to outsource the determination of custom to treaties, non-binding documents, doctrine or international judicial practice. Sometimes, it appears that domestic courts simply assert, without citing persuasive practice authority, the existence of a customary norm. In rare cases, however, domestic courts do engage in extensive analysis.
\end{abstract}

Keywords Customary international law · Domestic courts · Methodology · Treaties · Doctrine

\footnotetext{
This article has been completed on 22 January 2018. The research which resulted in this publication has been funded by the European Research Council under the Starting Grant Scheme (Proposal 336230_UNIJURIS) and the Dutch Organization for Scientific Research under the VIDI Scheme (No. 016.135.322).

Cedric M. J. Ryngaert C.M.J.Ryngaert@uu.nl

Duco W. Hora Siccama dhorasiccama@gmail.com

1 Professor of Public International Law, Utrecht University, Utrecht, The Netherlands

2 Graduate Researcher, Utrecht University, Utrecht, The Netherlands
} 


\section{Introduction}

In the formalist understanding of the sources of international law, ${ }^{1}$ a norm becomes a norm of international law insofar as it has been generated by accepted processes of international law formation. The existence of a norm of customary international law, in line with the dominant understanding of custom as a source of international law, is only acknowledged when sufficient evidence of state practice and opinio juris is adduced. ${ }^{2}$ There is no agreement, however, on the precise method to be used to determine specific norms of custom, or on how to make sense of disparate evidentiary materials. Reflecting on the method used by the International Court of Justice (ICJ), Stefan Talmon has submitted that 'when determining the rules of customary international law, the ICJ does not use one single methodology but, instead, uses a mixture of induction, deduction and assertion' ${ }^{3}$ In most cases, the ICJ simply asserts or posits the customary norm, without strong evidentiary backing. ${ }^{4}$ This concern was also raised by the Asian-African Legal Consultative Organisation (AALCO) Informal Expert Group on Customary International Law. The ICJ's lack of rigorous customary international law-identification methodology has even been admitted (although at the same justified on pragmatic grounds) by a former President of the Court. ${ }^{6}$

What this means is that a determination of the law may not depend on the community of states' opinio juris, but on the opinio juris of the ICJ itself. This suggests that the ICJ has considerable agency, if not simple discretion in determining whether a claimed norm enjoys customary status, thus making the process of content-determination of the sources of international law a rather unpredictable endeavour. ${ }^{7}$

A similar process can be witnessed in the practice of domestic courts determining norms of customary law. Inevitably, a somewhat messy picture emerges from this practice, but it is striking that in the large majority of decisions, courts offer little in

\footnotetext{
1 See on formalism: d'Aspremont (2011).

2 Art. 38(1)(b) Statute of the International Court of Justice. See ILC Special Rapporteur (2014), p. 72 ('To determine the existence of a rule of customary international law and its content, it is necessary to ascertain whether there is a general practice accepted as law').

3 Talmon (2015), p. 443. Induction is being understood as a method of inferring the customary norm from an iterative process of state practice and opinio juris. Deduction infers a specific customary norm (e.g., immunity from jurisdiction) from a more general principle (e.g., the principle of sovereign equality). Assertion means that the ICJ neither uses inductive nor deductive reasoning, but simply asserts customary international law. Ibid., pp. 420, 434.

4 Ibid., pp. 434-440.

5 AALCO IELG, Report of 24 March 2015, available at http://www.aalco.int/54thsession/AALCOIEG\% 20Chairman\%27s\%20Statement\%20and\%20Special\%20Rapporteur\%27s\%20Report\%2020150324.pdf (accessed 20 January 2018).

6 Tomka (2016), p. 5.

7 Compare also Prosecutor v. Kupreškić, 14 January 2000, IT-95-16-T, para. 527, finding a rule of customary international law, citing 'the demands of humanity or the dictates of public conscience', in the face of scarce state practice. Arajärvi (2017), pp. 189-190.
} 
the way of evidence supporting the existence of the posited customary norm. ${ }^{8}$ In so doing, they largely mimic the ICJ's approach, ${ }^{9}$ although offering even less evidence than the ICJ does. ${ }^{10}$ In particular, while they duly pay lip-service to the two constitutive elements of custom (state practice and opinio juris), ${ }^{11}$ the analysis of state practice-supposedly the backbone of the process of customary norm determination process-is generally shallow, ${ }^{12}$ and findings as to the (non-) existence of a customary norm may appear to be of an oracular nature. ${ }^{13}$

This article shows, on the basis of a large number of cases, that domestic courts, when determining custom, use other materials as proxies for a thorough analysis of state practice and opinio juris. The article is a comparative categorisation study of the methods used by domestic courts to identify customary international law. The research is methodologically based on grounded theory, a social science-based qualitative research approach, which constructs theory inductively on the basis of data analysis. Grounded theory works on the basis of coding, conceptualizing, and categorizing data with a view to generating dense theory. ${ }^{14}$ No specific legal systems or explanatory theories were selected beforehand, as such would have limited the scope of the research. The aim was instead to show the prevailing divergence of identification methods that are globally in use. ${ }^{15}$ While it is theoretically possible to examine cases without a specific demarcation in time, for a proper understanding of contemporary identification practices, the authors have examined domestic court decisions rendered between 2000 and 2016. For reasons of practical feasibility as well as to understand contemporary rather than historic court practices, it was decided to limit the sample to cases decided from 2000 onwards.

In social-scientific research, sample size should be large enough to reach theoretical saturation, i.e., a situation where '(a) no new or relevant data seem to emerge regarding

\footnotetext{
${ }^{8}$ See also Stirling-Zanda (2004), p. 3 (submitting that domestic courts tend to offer little evidence of state practice and opinio juris).

9 ILC Special Rapporteur (2013a), para. 84; Stirn (2013), p. 267.

10 ILC Special Rapporteur (2013a), para. 85.

11 See however $C$ v. Director of Immigration, First instance, HCAL 132/2006, [2008] 2 HKC 165, [2008] HKCFI 109, ILDC 1119 (HK 2008), 18 February 2008, High Court as Court of First Instance, para. 65 (adding a third element, namely that a rule of customary law should be of a norm-creating character). This third element is rather obvious, however, and is also implicit in the methodology used by international courts.

12 See, e.g., with respect to Italian courts: Pavoni (2007), p. 212.

13 E.g. Ali Shafi and ors v. Palestinian Authority and Palestinian Liberation Organization, Appeal judgment, 642 F3d 1088 (DC Cir 2011), ILDC 2130 (US 2011), 14 June 2011, United States; Court of Appeals (DC Circuit) [DC Cir] (citing without much evidence that there was no sufficiently universal norm of international law to support such a concept that would endorse the creation of an Alien Tort Statute cause of action for torture against a non-state actor, para. 22). See for ready acceptance that the 1968 Statutory Limitations Convention reflects customary international law: Chile v. Arancibia Clavel (Enrique Lautaro), Appeal Judgment, Case No. 259, A 533 XXXVIII, ILDC 1082 (AR 2004), 24 August 2004, Supreme Court [CSJ], paras. 28, 32; Ellacuría Beascoechea and ors v. President of El Salvador and ors, Writ of amparo, 674-2001, ILDC 1455 (SV 2003), 23 December 2003, Supreme Court of Justice, para. 190.

14 Corbin and Strauss (2015).

15 See for the method of selecting legal systems in light of the aim of the research: Oderkerk (2015), p. 608 .
} 
a category, (b) the category is well developed in terms of its properties and dimensions demonstrating variation, and (c) the relationships among categories are well established and validated ${ }^{16}$ or large enough to have sufficient 'information power'. ${ }^{17}$ Methodologists do not set a minimum sample size, as this depends on the context and the research question. To answer the research question posed in this article and to increase theoretical validity, it was considered important to identify as many relevant decisions (data) as possible, from as many different jurisdictions as possible. Any domestic case in which the court ascertained customary international law, using one of the methods mentioned below, was considered relevant.

Cases have been largely drawn from the databases International Law in Domestic Courts (ILDC) of Oxford University Press, and International Law Reports (ILR) of Cambridge University Press. Basic keywords, such as 'customary international law' or any equivalent or translation thereof were used to identify the cases. The cases were not selected based on their geographical location, but based on their relevance in relation to the keywords. ${ }^{18}$ We initially identified 300 cases, of which 60 turned out to be relevant. We cannot exclude the existence of other relevant cases that have not been reported in ILDC or ILR. National reporters for these databases may be inactive, or even non-existent, as a result of which domestic cases relevant to customary international law may not have been reported. Whether ILDC or ILR suffer from reporting bias is not part of our inquiry, however.

The focus of the examination has been placed on the methods or techniques used by domestic courts to identify norms of customary international law, with a view to identifying methodological categories. To this effect, all data, i.e., all domestic court decisions, which were based on customary international law, have been coded by both authors. This led to the categorisation of the data in a number of provisional subcategories, ${ }^{19}$ and, after conceptual saturation was reached in the data analysis, in five final categories, i.e., five customary law identification methods used by domestic courts. Obviously, reasonable observers may take issue with this categorisation and take the view that other categories may be more apt to systemize the data. ${ }^{20}$ Such alternative views may be entirely legitimate. The authors

\footnotetext{
${ }^{16}$ Corbin and Strauss (1998), p. 212.

${ }^{17}$ Malterud et al. (2016), pp. 1752-1760.

${ }^{18}$ Cases were drawn from Australia, Austria, Belgium, Canada, France, Germany, Ghana, Hong Kong, Italy, Kosovo, the Netherlands, Philippines, Poland, South Africa, Singapore, Sweden, the United Kingdom, the United States of America and Zimbabwe.

${ }^{19}$ E.g., in an initial phase of the research 'executive statements regarding CIL' and 'simple assertion of CIL' were identified as relevant (sub-)categories of techniques used by domestic courts. These were eventually integrated into broader, final categories.

${ }^{20}$ E.g., for slightly different, although overlapping categories capturing the ICJ's method of customary international law-identification: Tomka (2016), p. 24 ('The Court has taken a pragmatic approach to determining the existence and content of international custom, considering whether a rule has been convincingly identified before moving on to consider the primary evidence of State practice and opinio juris. In this regard, four particular methods for the assessment by the Court of evidence of customary law have played an important role: (1) referring to multilateral treaties and their travaux preparatoires, (2) referring to UN resolutions and other non-binding documents which are drafted in normative language, (3) considering whether an established rule applies to current circumstances as a matter of deduction and (4) resorting to an analogy').
} 
considered the chosen categories as being most adequate to capture the practice in domestic courts, and being most useful for pedagogical purposes. As they are the outcome of empirical research, they should by no means be used in a prescriptive manner: this contribution does not, and does not aspire to offer precise guidelines regarding how domestic courts should identify customary international law.

Most of the identified methods draw on other (legal) materials. Indeed, only rarely does a domestic court thoroughly examine relevant state practice and opinio juris at length. ${ }^{21}$ Instead, domestic courts tend to draw on multilateral treaties (Sect. 2), authoritative non-binding instruments (Sect. 3), the doctrine (Sect. 4), and international judicial practice (Sect. 5). Exceptionally, domestic courts conduct an extensive analysis of state practice and opinio juris (Sect. 6).

The focus of the article lies on categorising domestic court practices, which contribute to a more systematic understanding of such practices. However, the article also signals, from an evaluative perspective, problematic aspects of techniques applied by domestic courts. The judgmental yardstick used for this evaluative analysis is the requirement, drawn from the classic theory of customary norm formation, that a customary norm evidences 'a general practice accepted as law', ${ }^{22}$ which in principle requires a thorough analysis of state practice and opinio juris. $^{23}$ The normative perspective in this article is however subordinate to its primary systematisation objective.

This article only addresses the customary international law-identification methods used by domestic courts. It does not as such examine the normative impact which domestic court decisions have had on the formation of customary international law, or on the decisions of domestic courts in other jurisdictions confronted with similar questions. ${ }^{24}$ Nor does it carry out a comparative analysis of whether there are any differences in how particular states or groups of states (such as civil law versus common law states) identify customary international law.

\footnotetext{
${ }^{21}$ E.g. Reinisch and Bachmayer (2012), p. 10 (demonstrating, on the basis of an empirical study of post 1945 Austrian judgments, that Austrian courts rarely conduct an extensive analysis of state practice and opinio juris). In fact, only in one case did a court engage in such an analysis. See Dralle v. Republic of Czechoslovakia, OGH 1 Ob 171/50, SZ 1950 No. 23/143, 17 ILR 155, 10 May 1950, Austria; Supreme Court, pp. 157-163.

${ }^{22}$ Art. 38(1)(b) Statute of the International Court of Justice.

${ }^{23}$ A rigorous application of the two-element approach is also the yardstick suggested by the AALCO Informal Expert Group on Customary International Law. See Yee (2016), p. 37 ('The AALCOIEG agreed that the two-element approach was the proper one but was very concerned about the uneven rigor with which international courts and tribunals applied it in the identification of customary international law rules in their decisions, in identification operations which were sometimes described as "pragmatic", "truncated", "incomplete", "untidy" or "assertive").

${ }^{24}$ See on this e.g., Roberts (2011), p. 62; Ryngaert (2017).
} 


\section{Multilateral Treaties}

Very much like the ICJ, ${ }^{25}$ domestic courts may consider widely, or at times less widely $^{26}$ ratified multilateral treaties as evidence of the existence of customary international norms (or general principles). Thereby, they dispense with a detailed analysis of state practice or opinio juris. They may do so because they feel more comfortable with written sources of law, ${ }^{27}$ or because state parties to treaties already accepted that certain provisions are declaratory of customary international law. ${ }^{28}$ Referring to treaties may be problematic, however, insofar as there is no existing law, no 'general practice accepted as law by states' on the subject. This is arguably the case for most treaties. ${ }^{29}$ Accordingly, domestic courts will tend to consider treaty provisions as reflecting customary norms in case of widespread ratification of the treaty. ${ }^{30}$ The practice of states which ratified the treaty and act in accordance with the latter's provisions, is then considered as evidencing state practice and opinio juris for customary law purposes. ${ }^{31}$ A US court has for instance held that 'a treaty will only constitute sufficient proof of a norm of customary international law if an overwhelming majority of States have ratified the treaty, and those States uniformly and consistently act in accordance with its

\footnotetext{
25 Talmon (2015), pp. 437-438, cases cited in footnotes 145-149.

26 E.g. with respect to the European Convention on State Immunity, which is ratified by only eight states: Azeta BV v. Chile, Supreme Court decision, ECLI:NL:HR:2010:BK9154, 08/03023, ILDC 1165 (NL 2010), 26 March 2010, Supreme Court [HR], para. 3.8.2; Heusala v. Turkey, Appeal judgment, KKO:1993:120, 1993 II at 563, ILDC 576 (FI 1993), 30 September 1993, Supreme Court, para. 8.

27 Unwritten sources are indeed rarely invoked in domestic litigation, especially in civil law countries. See Wouters (2004), p. 32.

28 See for example Gramara (Private) Limited and ors v. Government of Zimbabwe and AttorneyGeneral of Zimbabwe, Decision on the registration of an international judgment, HH 169/2009, ILDC 1746 (ZW 2010), 29 January 2010, Zimbabwe; High Court, paras. 46-47 (The court states that pacta sunt servanda is a principle of CIL, which is codified in the Vienna Convention on the Law of Treaties); Regina (on the application of Kibris Turk Hava Yollari and CTA Holidays Limited) v. Secretary of State for Transport (Republic of Cyprus, interested party), EWHC 1918 Admin, 148 ILR 683, 28 July 2009, England; High Court, Queen's Bench Division, para. 37 ('it is accepted by the parties that art 1 of the Convention is declaratory of customary international law').

29 Choi and Gulati (2016), p. 124.

${ }^{30}$ Ministry of the Interior v. BM and BS, Final appeal judgment, No. 9377/2011, ILDC 2040 (IT 2011), 27 April 2011, Italy; Supreme Court of Cassation, 1st Civil Section, para. 2.01; Bayan v. Romulo, Muna v. Romulo and Ople, Petition for certiorari, mandamus, and prohibition, GR no. 159618, ILDC 2059 (PH 2011), 1 February 2011, Philippines; Supreme Court, para. 96; Chiquita Brands International Incorporated and ors v. Valencia and ors, Decision on motion to dismiss, Case No. 08-01916-MDMARRA, ILDC 1873 (US 2011), 792 F Supp 2d 1301 (SD Fla 2011), 3 June 2011, United States; Florida; District Court for the Southern District of Florida, para. 49. All conclude that certain conventions do not reflect CIL because of the low number of ratifications.

31 Technically, however, opinio juris means that a state acts out a belief that the customary rule is binding and not that it acts because of a binding treaty provision. E.g. United States $v$. Hasan and ors, Decision on motion to dismiss, No. 2:10cr56, ILDC 1586 (US 2010), 29 October 2010, United States; Virginia; District Court for the Eastern District of Virginia, paras. 87-90 (161 states ratified the Convention out of a sense of agreement, which in this case, is a treaty obligation); Ure v. Commonwealth of Australia and Director of National Park, FCA 241, 164 ILR 304, 17 March 2015, Australia; Federal Court, paras. 119-120 (arguing that a treaty is an agreement between states and not necessarily a recognition of a pre-existing obligation).
} 
principles' ${ }^{32}$ In another case, a court ruled that, while a number of specially affected states had ratified relevant treaties, as those states did not act in accordance with the provisions of those treaties, they could not be considered as reflecting customary international law. ${ }^{33}$

Insofar as treaties have been very widely ratified, and pertain to human rights or international humanitarian law, domestic courts tend to conceive of such treaties as reflecting custom, without submitting elaborate evidence in terms of state practice and opinio juris. Thus, relying on treaty law, domestic courts have held that torture is a violation of the law of nations, ${ }^{34}$ and that genocide is a specific intent crime. ${ }^{35}$ Courts have satisfied themselves with relying on the Geneva Conventions to the effect that there is a customary international law norm stipulating that opposing sides in a time of armed conflict are to ensure the well-being of the civilian population and to respect its dignity and basic rights, ${ }^{36}$ and that a distinction should be made between combatants and civilians, ${ }^{37}$ as no one would contest that these are basic principles of humanitarian law. Likewise, the prohibition of slavery is also considered as 'one of the most well-established customary rules'. ${ }^{38}$

Given the widespread ratification of the aforementioned relevant treaties, and the fundamental nature of the relevant norms, which may even amount to jus cogens (peremptory) norms, ${ }^{39}$ such a law-ascertainment method may appear legitimate.

\footnotetext{
32 United States v. Hasan and ors, Decision on motion to dismiss, No. 2:10cr56, ILDC 1586 (US 2010), 29 October 2010, United States; Virginia; District Court for the Eastern District of Virginia, para. 87. As such, it considers the definition of piracy in the UN Convention on the Law of the Sea (UNCLOS) as reflective of customary international law, because 161 states had ratified the Convention, which represents the 'overwhelming majority'. Ibid., para. 89.
}

33 United States v. Bellaizac-Hurtado and ors, Appeal judgment, 700 F3d 1245 (11th Cir 2012), ILDC 1949(US 2012), 6 November 2012, United States; Court of Appeals (11th Circuit), para. 26 (concerning drug-trafficking). See also United States v. Del Carmen Cardales-Luna, Appeal judgment, 632 F3d 731 (1st Cir 2011), ILDC 1777 (US 2011), 20 January 2011, United States; Court of Appeals (1st Circuit), dissenting opinion, para. 43 (considering drug trafficking not to be CIL, as drug trafficking is not incorporated in UNCLOS).

34 Filartiga v. Pena-Irala, Appeal judgment, 630 F 2d 876 (2nd Cir 1980), ILDC 681 (US 1980), 30 June 1980; Almog and ors v. Arab Bank, Public Limited Company, Trial court decision on motions, 471 F.Supp.2d 257 (E.D.N.Y. 2007), ILDC 801 (US 2007), 29 January 2007, District Court for the Eastern District of New York [E.D.N.Y.], para. 35 (citing a large number of international instruments); Mann $v$. Republic of Equatorial Guinea, 153 ILR 697, 23 January 2008, Zimbabwe; High Court, paras. 703, 711 (referring to international and regional human rights instruments).

35 E.g., Abagninin and ors v. AMVAC Chemical Corporation and ors, Appeal judgment, No. 07-56326, 545 F.3d 733 (9th Cir. 2008), ILDC 1106 (US 2008), 24 September 2008, Court of Appeals (9th Circuit) [9th Cir.], para. 22.

36 Al-Basyuni Ahmad and ors v. Prime Minister and Minister of Defence, Original Petition, Case No. HCJ 9132/07, ILDC 883 (IL 2008), 30 January 2008, Supreme Court as Court of First Instance, paras. 13-14.

37 Public Committee against Torture in Israel and Palestinian Society for the Protection of Human Rights and the Environment v. Israel and ors, Original Petition to the High Court of Justice, Case No. HCJ 769/02, ILDC 597 (IL 2006), 14 December 2006, Supreme Court as Court of First Instance, paras. 23-28.

38 Velez and Sanchez (intervening) v. Sanchez and ors, Appeal decision, 693 F3d 308 (2012), ILDC 1926 (US 2012), 31 July 2012, United States; Court of Appeals (2nd Circuit), paras. 24-27. In a case in which a US Court of Appeals had to decide on whether modern variants of slavery (forced labour, servitude) are also considered as customary international law, which the Court confirmed after examining different treaties.

39 E.g., Supreme Court of Canada (2014), Kazemi Estate v. Iran, 159 ILR 299, paras. 48-49, citing Jones v. Ministry of the Interior of Saudi Arabia, [2006] UKHL 26 [2007] 1 AC 270 (considering the prohibition of torture to be a peremptory norm, after giving an overview of its codification in various conventions). 
However, doubts can be raised over the legitimacy of relying on multilateral treaties as evidence of custom when these treaties are not widely ratified, and when state practice is not widespread or even at loggerheads with the text of the treaty. Thus, domestic courts should be cautious to consider the Rome Statute of the International Criminal Court $^{40}$ or treaties on state succession as reflective of customary international law. Not all courts have demonstrated such caution. ${ }^{41}$ Even more caution is needed when a treaty has not even entered into force, e.g., the UN Convention on Jurisdictional Immunities of States, ${ }^{42}$ in which case additional evidentiary materials may be required. ${ }^{43}$

To their credit, some domestic courts realise the trap of deriving custom from multilateral treaties, and may make an effort at referring to concordant

\begin{abstract}
${ }^{40}$ Rome Statute of the International Criminal Court (last amended 2010), adopted 17 July 1998, in force 1 July 2002, ISBN No. 92-9227-227-6.

${ }^{41}$ See, e.g., Kenya section of the International Commission of Jurists v. Attorney General and Minister of State for Provincial Administration and Internal Security and Kenyans for Justice and Development Trust (joining), Final judgment, [2011] eKLR, ILDC 1804 (KE 2011), 28 November 2011, High Court, para. 76 ('Obligations under the Rome Statute are customary international law'); SRYYY v. Minister for Immigration and Multicultural and Indigenous Affairs, Judgment, [2005] FCAFC 42, ILDC 981 (AU 2005), 17 March 2005, Federal Court [FCA], para. 75 (holding the Rome Statute was expressive of customary international law); Azov Shipping Company v. Werf- en Vlasnatie NV, Appeal judgment, (2001) Antwerp Maritime Law Rep 318, ILDC 43 (BE 2001), 19 March 2001, Court of Appeal, para. 4 (ruling that it was a rule of customary international law that successor states were not bound by treaties of their predecessors, relying on Art. 24 of the Vienna Convention on Succession of States in Respect of Treaties, as well as, for that matter, a Memorandum on Mutual Understanding on the Issue of Legal Succession in Relation to Treaties of the Former USSR Representing Mutual Interest (6 July 1992); AA, Constitutional complaint, Up-1299/06-16, ILDC 685 (SI 2007), 15 March 2007, Constitutional Court, Judge Škrk, concurring, para. 2 (relying on Vienna Convention on Succession of States in respect of State Property, Archives and Debts, Vol. II, United Nations Publication, Sales No. E.94.V.6, 8 April 1983); BA, Final ruling upon request for extradition, PN KR No. 386/2010, ILDC 1964 (KO 2010), 7 September 2010, Kosovo (disputed), paras. 28-29 (acknowledging that the Vienna Convention on Succession to Treaties is not in force in Kosovo, but simply stating that some of its provisions reflect customary international law, such as Art. 24). See for a cautious attitude, however: Bayan v. Romulo, Muna v. Romulo and Ople, Petition for certiorari, mandamus, and prohibition, GR no. 159618, ILDC 2059 (PH 2011), 1 February 2011, Supreme Court, paras. 95-96 (holding that 'the International Criminal Court, as an international tribunal founded in the Rome Statute, is not declaratory of customary international law', as it had only been ratified by 114 states); Russian Embassy, Re, Russian Federation, Final appeal/cassation, 5 Ob 152/04w, ILDC 4 (AT 2004), 9 November 2004, Supreme Court of Justice [OGH], para. 37 ('ascertainment and classification of doubtful international customary law is excluded as a requirement for affirmation of state succession in land register proceedings').

${ }^{42}$ UNGA, United Nations Convention on Jurisdictional Immunities of States and Their Property, adopted 2 December 2004, not yet in force, A/RES/59/38.

43 There are many examples of domestic courts simply considering the Convention as constituting customary law, and failing to elaborate on what grounds this would be so. See Société NML Capital v. Argentina, Appeal judgment, No. 11-10 450, ILDC 2075 (FR 2013), 28 March 2013, France; Court of Cassation [Cass]; Civil Division, para. 7. See also two Dutch and Swedish cases in which the Supreme Courts state that the UN Convention on Jurisdictional Immunities is a codification of customary international law, Ahmad v. de Staat der Nederlanden, 12/02548, ECLI:NL:HR:2013:45, 28 June 2013, Netherlands; Supreme Court, para. 3.6.2; Azeta BV v. Japan Collahuasi Resources BV and de Staat der Nederlanden, No. C07/054HR, ECLI:NL:HR:2008:BD1387, 11 July 2008, Netherlands; Supreme Court, para. 3.5; Bostadsrättsföreningen Villagatan 13 v. Belgium, Judgment of the Supreme Court, ö 2753, NJA 2009 s 95, ILDC 1672; Sedelmayer v. Russian Federation, Judgment, ILDC 1673 (SE 2011), NJA 2011 475, 1 July 2011, Sweden; Supreme Court (SE 2009), 30 December 2009, Sweden; Supreme Court, paras. 10,12 .
\end{abstract}


practice. ${ }^{44}$ Sometimes they may do so without further identifying this practice, ${ }^{45}$ but they might just as well be willing to engage in a rather detailed analysis of state practice, sometimes also with a view to proving that an invoked treaty norm does not reflect custom. ${ }^{46}$ As far as the latter method is concerned, the practice of US courts stands out in this respect. Through analysing state practice, the status of ratifications and state party reservations, US courts have held that customary international law did not prohibit military use of herbicides in spite of a 1925 Geneva Convention, ${ }^{47}$ that the International Convention for the Suppression of the Financing of Terrorism did not constitute customary international law, ${ }^{48}$ and that provisions of the Convention on the Rights of the Child did not necessarily reflect custom. ${ }^{49}$

Finally, some questionable practices may be flagged that replace rigorous scrutiny of state practice with an analysis of whether the convention containing the alleged customary norm is judicially enforceable (an approach which conflates

\begin{abstract}
${ }^{44}$ See generally Flores and ors v. Southern Peru Copper Corp, 414 F3d 233 (2d Cir 2003), ILDC 303 (US 2003), 15 April 2003, paras. 256-257 ('a treaty will only constitute sufficient proof of a norm of customary international law if an overwhelming majority of States have ratified the treaty, and those States uniformly and consistently act in accordance with its principles. The evidentiary weight to be afforded to a given treaty varies greatly depending on (i) how many, and which, States have ratified the treaty, and (ii) the degree to which those States actually implement and abide by the principles set forth in the treaty').

45 Amergi and ors v. Palestinian Authority and Palestine Liberation Organization, Appeal decision, 611 F3d 1350 (11th Cir 2010), ILDC 1577 (US 2010), 27 July 2010, Court of Appeals (11th Circuit) [11th Cir.], para. 20; Assemblies Case, Agešins and ors v. Parliament of Latvia (Saeima), Constitutional Review, Case No. 2006-03-0106, ILDC 1062 (LV 2006), 23 November 2006, Constitutional Court, paras. 28.3-28.4 (noting the general lack of consistent protest by states regarding the mere exercise of freedom of assembly outside embassies).

46 For an example of a court analysing state practice with a view to establishing the customary status of a treaty provision: The Queen v. Klassen, First Instance Judgment, Docket No. 24292, 2008 BCSC 1762, 240 CCC (3d) 328, 63 CR (6th) 373, 182 CRR 291, ILDC 941 (CA 2008), 19 December 2008, Supreme Court [BCSC], para. 93. The Court noted that at least 44 countries who were parties to the Optional Protocol to the Convention on the Rights of the Child had legislation similar to the article in the Criminal Code providing for universal jurisdiction over sexual offences against children; taking together with the fact that 129 countries had ratified the Protocol, this meant for the Court that the relevant provision was part of customary international law.
\end{abstract}

47 Agent Orange Product Liability Litigation, Re, Vietnam Association For Victims Of Agent Orange/ Dioxin and ors v. Dow Chemical Company and ors, First Instance, 373 F.Supp.2d 7 (E.D.N.Y. 2005), ILDC 123 (US 2005), 10 March 2005, District Court for the Eastern District of New York [E.D.N.Y.], para. 291.

48 Chiquita Brands International Incorporated and ors $v$. Valencia and ors, Decision on motion to dismiss, Case No. 08-01916-MD-MARRA, ILDC 1873 (US 2011), 792 F Supp 2d 1301 (SD Fla 2011), 3 June 2011, United States; Florida; District Court for the Southern District of Florida [SD Fla], paras. 50-52; Hamdan v. United States of America, 154 ILR 751, 16 October 2012, United States; United States Court of Appeals, District of Columbia Circuit, para. 1251 (referring to many conventions and statutes of Criminal Courts).

49 Flores-Nova and Castaño-Garduno (also known as Ariceli Flores Jesus Alberto Flores-Nova) v. Attorney General, Review of an order of the Board of Immigration Appeals, 652 F3d 488 (3d Cir 2011), ILDC 1795 (US 2011), 25 July 2011, Court of Appeals (3rd Circuit) [3d Cir.], para. 15 (with respect to Art. 3(1) of the Convention); Flomo and 22 additional child plaintiffs v. Firestone Natural Rubber Company, LLC, Appeal judgment, 643 F3d 1013 (7th Cir 2011), ILDC 1775 (US 2011), 11th July 2011, United States; Court of Appeals (7th Circuit), paras. 23-30. 
validity with enforceability), ${ }^{50}$ whether the convention is not just aspirational and vague (which betrays a concern over judicial law-making to the detriment of the foreign policy prerogatives of the political branches), ${ }^{51}$ or whether it concerns a 'matter of universal concern' (which conflates formal validity with the substantive content and scope of obligations of the norm). ${ }^{52}$ Also of note is the practice of admitting that a multilateral treaty not ratified by the forum state does not constitute customary international law, but nevertheless going on to apply its provisions on the ground that customary law is too difficult to determine. ${ }^{53}$ The latter methodology, which is arguably inspired by the wish to prevent a non liquet, obviously makes a mockery of the theory of custom-formation.

\section{Authoritative Non-Binding Instruments}

The ICJ has the habit of regarding non-binding instruments such as UN General Assembly resolutions and Draft Articles of the International Law Commission (ILC) as, under some circumstances, reflective of customary international law, again without much analysis of its own. ${ }^{54}$ Domestic courts are not much different: while sometimes conceding that these instruments are as such not binding, they may readily apply their provisions to the case at bar. ${ }^{55}$ Like the ICJ, domestic courts have considered (some) ILC Articles, UN General Assembly Resolutions (such as the Universal Declaration of Human Rights), ${ }^{56}$ or conventions that had not been ratified

\footnotetext{
50 Calcaño Pallano and ors v. AES Corporation and ors, Consolidated trial judgment, CA No. N10C-04054, ILDC 1830 (US 2011), 15 July 2011, United States; Delaware; Superior Court, para. 62.

51 Stirling-Zanda (2004), p. 5 (referring to the political potential of the application of customary norms lacking precision); Calcaño Pallano and ors v. AES Corporation and ors, Consolidated trial judgment, CA No. N10C-04-054, ILDC 1830 (US 2011), 15 July 2011, United States; Delaware; Superior Court, para. 64 (The United States Court of Appeals for the Second Circuit found the UN Convention on the Rights of the Child was 'extremely vague, clearly aspirational in nature, and does not even purport to reflect the actual customs and practices of States').

52 Calcaño Pallano and ors v. AES Corporation and ors, Consolidated trial judgment, CA No. N10C-04054, ILDC 1830 (US 2011), 15 July 2011, Superior Court [Del. Super.], paras. 62-71; Flores and ors $v$. Southern Peru Copper Corp, 414 F3d 233 (2d Cir 2003), ILDC 303 (US 2003), 15 April 2003, para. 63; Flomo and 22 additional child plaintiffs v. Firestone Natural Rubber Company, LLC, Appeal judgment, 643 F3d 1013 (7th Cir 2011), ILDC 1775 (US 2011), 11th July 2011, Court of Appeals (7th Circuit) [7th Cir.], paras. 27-28 (on these grounds refusing to acknowledge that provisions of respectively the Basel Convention, UNCLOS, the Convention on the Rights of the Child, and ILO Conventions nos. 138 and 182 could be customary international law).

53 Aziz and ors v. Alcolac, Inc. and ors, Appeal judgment, 658 F3d 388 (4th Cir 2011), ILDC 1878 (US 2011), 19 September 2011, Court of Appeals (4th Circuit) [4th Cir], para. 47 (holding that granting the Rome Statute preference over customary international law to resolve the issue was particularly appropriate given the elusive characteristics of customary international law).

54 Boyle (2004), p. 64; Talmon (2015), pp. 437-438.

55 Mann v. Republic of Equatorial Guinea, 153 ILR 697, 23 January 2008, Zimbabwe; High Court, para. 711 (referring to a General Assembly Resolution).

56 For instance, Supreme Court of Canada (2014), Kazemi Estate v. Iran, 159 ILR 299, para. 48. The Court relied, inter alia, on the Universal Declaration of Human Rights to establish the existence of the international prohibition of torture, apparently considering the Declaration as customary international law. However, the Court also relied on the UN Convention against Torture, jus cogens, and national law regarding the same prohibition.
} 
or had not entered into force, to be largely reflective of customary international law. ${ }^{57}$ Notably domestic court practice with respect to the ILC Draft Articles (and the later UN Convention) on the Jurisdictional Immunities of States, ${ }^{58}$ and the ILC Draft Articles on the Responsibility of States and International Organizations for Internationally Wrongful Acts ${ }^{59}$ stands out.

ILC Articles are of course imbued with a rather high degree of legitimacy, emanating from a UN body tasked with codifying international law. ${ }^{60}$ However, domestic courts may also rely on far more contestable non-binding instruments, a scientific consensus, or just proper policy, to buttress a predetermined outcome, or at least one reached on other grounds. ${ }^{61}$ For example, the English Court of Appeal cited a non-binding resolution adopted by the Institut de Droit International concerning the customary immunity of heads of state. ${ }^{62}$ The Hong Kong Court of First Instance referred to a 'roundtable' of 35 experts who concluded that the principle of nonrefoulement of refugees is a principle of customary international law, as well as to the non-binding San Remo Declaration on the Principle of Non-Refoulement. ${ }^{63}$ The Federal Constitutional Court of Serbia asserted that a document on the independence of the judiciary adopted by just one expert meeting contained generally accepted principles of international law, ${ }^{64}$ without citing any further evidence. Finally, the

57 Tomka (2016), p. 11. But see Boyle (2004), p. 64 (submitting that 'there is no evidence that any
common law court has ever referred to the work of the ILC').
58 AA v. Austrian Embassy, Final Decision on Jurisdiction, Case No. 05S3279, ILDC 826 (PT 2007), 18 58 AA v. Austrian Embassy, Final Decision on Jurisdiction, Case No. 05S3279, ILDC 826 (PT 2007), 18
February 2006, Supreme Court, para. VII (applying Article 11(2)(b) of the ILC Articles); Bostadsrättsföreningen Villagatan 13 v. Belgium, Judgment of the Supreme Court, Ö 2753-07, NJA 2009 s 95, ILDC 1672 (SE 2009), 30 December 2009, Supreme Court (applying Art. 2 of the UN Convention).

59 Olleson (2013), p. 641 ('there is a certain general tendency for domestic courts to simply apply the ILC's Articles (and the Articles on Responsibility of International Organizations) as if they were a legislative text, with little independent analysis of the extent to which the individual provisions which they are called upon to apply in fact represent customary international law'); Staat der Nederlanden $v$. Mustafic c.s., 12/03329, ECLI:NL:HR:2013:BZ9228, 6 September 2013, the Netherlands; Supreme Court, para. 3.7; Staat der Nederlanden v. Nuhanovic, 12/03324, ECLI:NL:HR:2013:BZ9225, 6 September 2013, Netherlands; Supreme Court, para. 3.7. The Supreme Court of the Netherlands considered Art. 7 of the ILC Draft Articles on the Responsibility of International Organizations for Internationally Wrongful Acts as simply reflective of the current state of the law, and went on to hold that, on that basis, the State of the Netherlands was in effective control over the conduct of peacekeepers deployed in safe areas around Srebrenica in 1995; Varvarin Bridge Case, 36 citizens of Yugoslavia v. Germany, Constitutional complaint, 2 BvR 2660/06, 2 BvR 487/07, ILDC 2238 (DE 2013), EuGRZ 2013, 563, DÖV 2013, 946, 13 August 2013, Germany; Constitutional Court, para. 43.

${ }^{60}$ Argentine Necessity Case, Case No. 2 BvM 1-5/03, 1, 2/06, 138 ILR 1, 8 May 2007, Germany; Federal Constitutional Court, para. 2.

61 Also Mendelson (2004), p. 84; Kirby (2008), p. 187 (referring to critics of this practice of cherrypicking).

62 HRH Prince Abdul Aziz bin Fahd bin Abdul Aziz v. Harb, EWCA Civ 481, 168 ILR 656, 13 May 2015, England; Court of Appeal, para. 37.

${ }^{63} C$ and Others v. Director of Immigration, 138 ILR 537, 18 February 2008, Hong Kong Special Administrative Region; Court of First Instance, paras. 103-104.

64 Certain amendments to the Serbian Law on Judges, Supreme Court of the Republic of Serbia and ors v. People's Assembly of the Republic of Serbia, Original petition for constitutional review, No. 17/2003, ILDC 31 (CSXX 2003), 13 February 2003, Federal Constitutional Court. 
District Court of The Hague in a public interest climate change litigation against the State of the Netherlands, cited such non-binding international instruments as a decision of the Ad hoc Working Group of Kyoto Protocol Annex I-states, ${ }^{65}$ and the outcome of a European Council summit, ${ }^{66}$ and partially on that basis ordered the State to reduce the joint volume of Dutch annual greenhouse gas emissions by at least 25 per cent at the end of 2020 compared to the level of the year $1990 .{ }^{67}$ None of the just-cited instruments would normally produce direct legal effects in municipal legal orders.

A special class of non-binding authoritative instruments on which courts rely to establish the customary nature of treaty provisions are the travaux préparatoires or preamble of a treaty. The Dutch Supreme Court, for instance, held that Article 19 of the UN Convention of Jurisdictional Immunities (a convention not yet in force for that matter) reflects customary international law, because the preamble states that jurisdictional immunities are generally accepted as customary international law. ${ }^{68}$ Surprisingly, a Belgian Court of Appeal considered the same article not to be reflective of customary law, by referring to the travaux préparatoires. ${ }^{69}$

Another class of non-binding instruments, which domestic courts have considered as persuasive authority regarding the identification of customary international law, are statements by the executive branch of government. This is a common practice in the United States, where courts may sometimes accept at face value executive determinations regarding the existence, or not, of customary norms, without an analysis of their own. ${ }^{70}$ In so doing, they effectively outsource the customary law identification process to the Executive. In other cases, courts may rely only in part on executive determinations regarding the (non-)existence of customary norms, while still treating them as authoritative enunciations. ${ }^{71}$

\footnotetext{
65 Cited in Urgenda Foundation v. State of the Netherlands, ECLI:NL:RBDHA:2015:7196, judgment of 24 June 2015, District Court of The Hague, para. 4.24.

66 Presidency Conclusions of the Brussels European Council (8/9 March 2007), 7224/1/07 REV 1, Brussels, 2 May 2007, available at http://www.consilium.europa.eu/uedocs/cms_data/docs/pressdata/en/ ec/93135.pdf (accessed 13 October 2017).

67 Urgenda Foundation v. State of the Netherlands, ECLI:NL:RBDHA:2015:7196, judgment of 24 June 2015, District Court of The Hague, para. 5.1.

68 Morning Star International Corporation v. Republic of Gabon and de Staat der Nederlanden, 16/01153, ECLI:NL:HR:2016:2236, 30 September 2016, Netherlands; Supreme Court, paras. 3.4.4, 3.4.6. Therefore, the Court refrained from undertaking an extensive analysis of whether this specific article indeed reflects customary international law.

69 NML Capital Ltd v. Argentina, Appeal judgment, 2009/AR/3338, ILDC 1803 (BE 2011), 21 June 2011, Belgium; Brussels; Court of Appeal, para. 36. The Dutch Court in the Morning Star case also refers to the travaux préparatoires with respect to Art. 18, which is not considered as customary international law (above n. 68, para. 3.4.7).

70 E.g., Hamdan v. United States of America, 154 ILR 751, 16 October 2012, United States; United States Court of Appeals, District of Columbia Circuit, para. 1251 (a case in which the Court deferred to the US Government's position that the 'offense of providing material support to terrorism, like spying and aiding the enemy, has not attained international recognition at this time as a violation of customary international law').

71 United States v. Bellaizac-Hurtado and ors, Appeal judgment, 700 F3d 1245 (11th Cir 2012), ILDC 1949 (US 2012), 6 November 2012, United States; Court of Appeals (11th Circuit), para. 28 (US court basing a part of its decision on a Memorandum filed by the US President to the effect that drug trafficking is not considered as a violation of customary international law).
} 
That domestic courts sometimes accept non-binding authoritative instruments as statements of positive law does not mean that they always do so. ${ }^{72}$ Courts may well put a high premium on the consent of states in the formation of international law, and on that ground refuse to accept soft law instruments as evidence of customary international law. ${ }^{73}$ There are a considerable number of domestic cases in which courts did not accept the customary status of provisions in ILC Draft Articles in the absence of sufficient state practice. As previously discussed with regard to the preamble and travaux préparatoires, a Belgian court considered that Article 19 of the ILC State Immunity Articles, which deals with the immunity from execution, was not a codification of customary international law. ${ }^{74}$ A year later, the ICJwhich should have had access to exactly the same contemporary state practiceconsidered the essence of the article to be reflective of customary law, or at least of a well-established practice. Regardless of the law-ascertainment methodology used, the ICJ's view is obviously more authoritative, but this goes to show that there appear to be discretionary elements in the customary international law identification, or at least that law-identifiers have considerable agency. ${ }^{75}$

A refusal to accept ILC Draft Articles as restatements of lex lata, could also be discerned from the English High Court's ruling that Article 8 of the ILC Draft Articles on Diplomatic Protection, which allowed diplomatic protection of refugees, was lex ferenda rather than lex lata ${ }^{76}$ and from a judgment of a German regional court with respect to Article 6 of the ILC Draft Articles on State Responsibility, which deals with attribution in cases of lending of state organs to another state. ${ }^{77}$ When rendering such decisions, domestic courts are not necessarily at loggerheads

\footnotetext{
72 Agent Orange Product Liability Litigation, Re, Vietnam Association For Victims Of Agent Orange/ Dioxin and ors v. Dow Chemical Company and ors, First Instance, 373 F.Supp.2d 7 (E.D.N.Y. 2005), ILDC 123 (US 2005), 10 March 2005, District Court for the Eastern District of New York [E.D.N.Y.], paras. 305, 309 (ruling that a UN General Assembly Resolution concerning an international prohibition of the use of herbicides in war was not an expression of international law).

73 Association France-Palestine Solidarité and Palestine Liberation Organization v. Société Alstom transport SA and ors, Appeal judgment, 11/05331, ILDC 2036 (FR 2013), 22 March 2013, France, para. 115.

74 NML Capital Ltd v. Argentina, Appeal judgment, 2009/AR/3338, ILDC 1803 (BE 2011), 21 June 2011, Court of Appeal, paras. 36-38. The Court substantiated this statement by referring to a non-binding recommendation of the Council of Europe, which shows different practices around Europe.

75 ICJ, Jurisdictional Immunities of the State (Germany v. Italy: Greece Intervening), Judgment of 3 February 2012, ICJ Report 2012, p. 99, para. 117.

${ }^{76} R$. and Office of the United Nations High Commissioner for Refugees (intervening) (on the application of Al Rawi and ors) v. Secretary of State for Foreign and Commonwealth Affairs and Secretary of State for Home Affairs, Appeal decision, [2006] EWCA Civ 1279, paras. 118-119.

77 Constance Regional Court, Case No. 4 O 234/05 H, judgment of 27 July 2006, discussed in Olleson (2013), pp. 626-627 (expressing doubts as to 'whether this legal concept has already evolved into customary law, although it is difficult to judge since there has not been sufficient practice on the issue [...]. It is also uncertain whether, in the absence of recognition as customary law, the rules on lending organs constitute a general principle of international law along the lines of article 38(1)(c) of the International Court of Justice Statute and article 6 of the International Law Commission [Articles]'). But see application by analogy in the context of the relationship between states and international organisations: HN v. Netherlands (Ministry of Defence and Ministry of Foreign Affairs), ECLI:NL:RBSGR:2008:BF0181, case no. 265615, ILDC 1092, The Netherlands; District Court for the Hague, 2008.
} 
with the ILC, however: after all, the ILC not only codifies international law, but also progressively develops it. The ILC may even openly admit that a particular rule which it lays down, amounts to progressive development of international law. Thus, in the commentary to the aforementioned Article 8 of the ILC Draft Articles on Diplomatic Protection, the ILC characterised the article as 'an exercise in progressive development of the law, [which] departs from the traditional rule that only nationals may benefit from the exercise of diplomatic protection', while citing, apparently approvingly, the English court's ruling that the article was 'not yet part of international law'. ${ }^{78}$

It is of note that where courts do accept non-binding instruments as positive law, possibly alongside other practice, individual judges may sometimes take issue with the majority's 'uncritical' evidentiary analysis, and its creation rather than 'determination' of a norm. ${ }^{79}$ Some international judges have criticised the majority in similar terms. ${ }^{80}$

When domestic courts do give legal effect to non-binding instruments, it bears emphasis that they may not just act as simple law-appliers (in case the customary character of the relevant provision had already been acquired and its scope of application been delimited), but also as veritable law-creators. As domestic court decisions count as instances of state practice, they may contribute to the hardening into positive law of norms that were initially meant only as progressive development of international law. This goes to show that domestic courts, on par with international courts and tribunals, might be active developers of international law, a point that recent doctrine has repeatedly emphasized. ${ }^{81}$

\footnotetext{
${ }_{78}$ Draft Articles on Diplomatic Protection, Yearbook of the International Law Commission, 2006, Vol. II, Part Two, UN Doc. A/61/10, Commentary (2), p. 48 referring to Al Rawi \& Others, $R$ (on the Application of) v. Secretary of State for Foreign Affairs and Another [2006] EWHC (Admin), para. 63.

${ }^{79}$ For instance, Judge Wesley of the US Court of Appeals for the Second Circuit, dissenting, wrote that, in respect of the instruments allegedly outlawing non-consensual medical experiments and cited by the majority, the ICCPR, the Convention on Human Rights and Biomedicine, the Declaration of Helsinki, and state practice held little or no weight, and the Nuremberg Code had only some evidentiary value, Abdullahi and Estate of Lubabatau Abdullahi v. Pfizer Incorporated, Appeal judgment, 562 F3d 163 (2d Cir 2009), 78 USLW 3049, ILDC 1232 (US 2009), 30 January 2009, Court of Appeals (2nd Circuit) [2d Cir.], para. 76. The same argument was actually made by the lower court in the case: Abdullahi III, Abdullahi (individually and on behalf of the Estate of Lubabatau Abdullahi) v. Pfizer Incorporated, Trial Decision on Remand, Case No. 01 Civ 8118 (WHP), ILDC 1091 (US 2005), 9 August 2005, District Court for the Southern District of New York [S.D.N.Y.].

${ }^{80}$ See as regards the ICJ: Arrest Warrant of 11 April 2000 (Democratic Republic of the Congo v. Belgium), ICJ Reports 2002, p. 3, diss. op. Judge van den Wyngaert, para. 16 (taking issue with the ICJ's finding that ministers of foreign affairs were, just like heads of state, entitled to absolute immunity from jurisdiction under customary international law); International Status of South West Africa, ICJ Reports 1950, p. 128, at pp. 159 and 162, Dissenting Opinion of Judge McNair (taking issue with the Court's determination that the UN succeeded to the League of Nations for purposes of the mandate system). See as regards the ICTY: Prosecutor v. Erdemovic, Separate and dissenting opinion of Judge Cassese, 7 October 1997, para. 41.

${ }^{81}$ Paulus (2013), p. 254. See also the special issue in Leiden Journal of International Law 2013, vol. 26, issue 3, pp. 531 et seq. on 'Domestic Courts as Agents of Development of International Law'.
} 


\section{Doctrine}

Unlike the ICJ, a considerable number of domestic courts seem to rely quite heavily on what the doctrine believes is custom. ${ }^{82}$ This is arguably so because domestic courts consider that they lack the required expertise to properly determine international law. ${ }^{83}$ Domestic courts may thus outsource their custom-determination to scholars, assuming — possibly mistakenly_that scholars have painstakingly and objectively analysed relevant practice. Examples of strong reliance on doctrine are legion. ${ }^{84}$ In the seminal case of United States $v$. Smith (1823), the US Supreme Court held that the definition of an offence under 'the law of nations' (i.e., customary international law) was determined (apparently primarily) on the basis of 'the works of jurists writing professedly on public law', apart from 'the general usage and practice of nations', and 'judicial decisions recognizing and enforcing that law, ${ }^{85}$ The Smith methodology was more recently confirmed in the Filartiga case (1980), which rediscovered the US Alien Tort Statute that gives aliens a cause of action in US federal courts for violations of the law of nations. ${ }^{86}$ The US Supreme Court also relied rather heavily on a study conducted by legal scholars when considering that the imposition of life sentences without parole on juveniles was cruel and unusual. ${ }^{87}$ It may even happen that courts refer to the views of scholars, without mentioning whose views they have consulted. ${ }^{88}$

\footnotetext{
${ }^{82}$ Moremen (2006), p. 306 (acknowledging that domestic courts 'simply do not have the time to engage in surveys of state practice').

83 Mendelson (2004), pp. 80-81.

${ }^{84}$ Hamburg Pirates Case, Office of Public Prosecutor of the Free and Hanseatic City of Hamburg v. CM and ors, Judgment, 603 KLs 17/10, ILDC 2390 (DE 2012), BeckRS 2013, 07408, 19 October 2012, Germany; Hamburg; Regional Court, para. 770 (relying on scholarly work that considers Art. 105 UNCLOS as CIL); Minister for Home Affairs (Cth) and Others v. Zentai and Others, HCA 28, 153 ILR 366, 15 August 2012, Australia; High Court, para. 22; Varvarin Bridge Case, 36 citizens of Yugoslavia v. Germany, Constitutional complaint, 2 BvR 2660/06, 2 BvR 487/07, ILDC 2238 (DE 2013), EuGRZ 2013, 563, DÖV 2013, 946, 13 August 2013, Germany; Constitutional Court, para. 43; FG Hemisphere Associates LLC v. Democratic Republic of the Congo and Others, 142 ILR 216, 10 February 2010, Hong Kong Special Administrative Region; Court of Appeal, paras. 71-76; HRH Prince Abdul Aziz bin Fahd bin Abdul Aziz v. Harb, EWCA Civ 481, 168 ILR 656, 13 May 2015, England; Court of Appeal, para. 37; Gramara (Private) Limited and ors v. Government of Zimbabwe and Attorney-General of Zimbabwe, Decision on the registration of an international judgment, HH 169/2009, ILDC 1746 (ZW 2010), 29 January 2010, Zimbabwe; High Court, para. 47; RB and TB v. Hellenic Republic, Interlocutory appeal judgment, 4Ob227/13f, ILDC 2214 (AT 2014), 20 May 2014, Austria; Supreme Court of Justice, para. 2; Velez and Sanchez (intervening) v. Sanchez and ors, Appeal decision, 693 F3d 308 (2012), ILDC 1926 (US 2012), 31 July 2012, United States; Court of Appeals (2nd Circuit), para. 24.

85 United States v. Smith (Thomas), Appeal Judgment, 18 US (5 Wheat.) 153 (1820), 5 L.Ed. 57 (1820), ILDC 1053 (US 1820), 2 February 1820, Supreme Court [U.S.].

86 Filartiga v. Pena-Irala, 630 F 2d 876 (2d Cir 1980), ILDC 681 (US 1980).

87 Graham v. Florida, Appeal judgment, Docket No. 08-7412, 560 US 48 (US 2010), ILDC 970 (US 2010), 17 May 2010, United States; Supreme Court, paras. 71-74. From the study it appeared that only eleven nations authorise such sentences and that the US and Israel are the only two states that have ever imposed it.

88 United States v. Bellaizac-Hurtado and ors, Appeal judgment, 700 F3d 1245 (11th Cir 2012), ILDC 1949 (US 2012), 6 November 2012, United States; Court of Appeals (11th Circuit), para. 26 ('Scholars also agree that drug trafficking is not a violation of contemporary customary international law').
} 
Courts rarely specifically reject any role for the doctrine in the determination of customary international law. ${ }^{89}$ That being said, while domestic courts may consider the doctrine important as a subsidiary source of international law for purposes of customary law determination, they will nonetheless often cite other evidence of the purported norm, or absence thereof. ${ }^{90}$ In this respect, domestic courts at times begin their process of identifying customary law by examining international judicial practice or treaties, but eventually base their conclusions on doctrinal analyses. ${ }^{91}$ Domestic courts' reliance on doctrinal sources again evinces that they may feel more comfortable referring to pre-existing 'written' evidence, identified by other agencies, in the process of customary law identification.

When relying on doctrine to determine customary international law, domestic courts may sometimes conveniently overlook the contestation within the doctrine regarding the existence or not of a customary rule. For instance, the Court of Appeals of Milan based the principle that there is no customary rule which recognised functional immunity from criminal proceedings for all state officials for acts performed in their official functions on 'authoritative doctrine' and 'univocal views of scholars', 92 although in reality there is no consensus on this

\footnotetext{
${ }^{89}$ Flores and ors v. Southern Peru Copper Corporation, Appeal judgment, Docket No. 02-9008, 414 F.3d 233 (2d Cir. 2003), ILDC 303 (US 2003), 29 August 2003, Court of Appeals (2nd Circuit) [2d Cir.], para. 86 ('expert affidavits of international law scholars lacked evidentiary value as proof of a customary international law prohibition on intra-national pollution').

90 E.g., Hamdan v. United States, Appeal judgment, 696 F3d 1238 (DC Cir 2012), ILDC 2022 (US 2012), 16 October 2012, Court of Appeals (DC Circuit) [DC Cir] (citing doctrine, but also conventions and international tribunal backing the stated norm); Varvarin Bridge Case, 36 citizens of Yugoslavia v. Germany, Constitutional complaint, 2 BvR 2660/06, 2 BvR 487/07, ILDC 2238 (DE 2013), EuGRZ 2013, 563, DÖV 2013, 946, 13 August 2013, Germany; Constitutional Court, para. 43 (discussing judicial practice, the ILC Articles of State Responsibility and doctrine); Helmerich \& Payne International Drilling Co and Helmerich \& Payne de Venezuela, CA v. Bolivarian Republic of Venezuela and ors, Trial judgment, 971 F Supp 2d 49 (DDC 2013), ILDC 2148 (US 2013), 20 September 2013, para. 16 (ruling that 'when there was no applicable treaty or federal precedent, a US court had to consider customary international law by examining the works of jurists and commentators as evidence of such').

91 Yong Vui Kong v. Public Prosecutor, 143 ILR 374, 14 May 2010, Singapore; Court of Appeal, paras. 95-96 (the Court relies on an 'extensive study of the status of the death penalty worldwide' by 'learned authors' for the purposes of identifying customary international law). See also Estate of Kazemi v. Islamic Republic of Iran and Others, 159 ILR 299, 10 October 2014, Canada; Supreme Court, para. 2 (the Court cites international case law, but bases its conclusion by referring to doctrine); Minister of Justice and Constitutional Development and Others v. Southern Africa Litigation Centre and Others, Case No. 867/15, 168 ILR 600, 15 March 2016, South Africa; Supreme Court of Appeal, para. 67; HRH Prince Abdul Aziz bin Fahd bin Abdul Aziz v. Harb, EWCA Civ 481, 168 ILR 656, 13 May 2015, England; Court of Appeal, paras. 35-37; United States v. Salad and ors, Decision on motion to dismiss, 908 F Supp 2d 730 (ED Va 2012), ILDC 2027 (US 2012), 30 November 2012, United States; Virginia; District Court for the Eastern District of Virginia, paras. 11-13 (the Court reaches its own conclusions, which are backed by legal doctrine).

92 'Abu Omar' case, General Prosecutor at the Court of Appeals of Milan v. Adler and ors, Final appeal judgment, No. 46340/2012, ILDC 1960 (IT 2012), 29 November 2012, 5th Criminal Section, para. 23.7. In Italy, the Supreme Court of Cassation had earlier cited the Smith principle approvingly in Vespignani $v$. Bianchi, Final Appeal on a Preliminary Question, Case No. 13711, Foro italiano I-428 (2005), ILDC 556 (IT 2004), 22 July 2004, Supreme Court of Cassation.
} 
principle. $^{93}$ The Canadian Supreme Court, for its part, drew heavily on academic works when positing that the precautionary principle in environmental law may be a customary international law norm, ${ }^{94}$ although there are other works that contest the customary character of the precautionary principle. ${ }^{95}$ Sometimes, courts are explicitly aware of a discussion in the doctrine on the existence of a customary norm, but nevertheless go on to apply (or 'create') the norm. The High Court of Hong Kong, for instance, while noting the absence of a universal consensus among academic writers regarding the customary status of the principle of nonrefoulement, eventually took the view that the principle did reflect customary international law on the ground that universal adherence to the principle was not required. ${ }^{96}$

\section{International Judicial Practice}

Most domestic courts embrace an attitude of deference to international courts when it comes to the determination of customary international law. They may do so out of respect for international courts' stronger expertise and legitimacy in matters of international law, ${ }^{97}$ possibly because they perceive international courts to be higher up in the judicial hierarchy, as well as out of concern about the uniform application of international law across jurisdictions. ${ }^{98}$ Again, the

\footnotetext{
93 See e.g. ILC Special Rapporteur (2013b), para. 50 on immunity of state officials in which the Rapporteur observed that ratione materiae is granted to all state officials in respect of official acts. See on the lack of consensus regarding immunity ratione materiae for international crimes and human rights violations: Crawford (2012), p. 500.

94 Canada Ltée (Spraytech, Société d'arrosage) and Services des espaces verts Ltée/Chemlawn v. Town of Hudson, Judgment of the Supreme Court, Docket No. 26937, 2001 SCC 40, [2001] 2 SCR 241, ILDC 185 (CA 2001), 28 June 2001, Supreme Court [SCC]. See also Waweru, Mwangi (joining) and ors (joining) v. Kenya, Miscellaneous civil application, Case No. 118 of 2004, App. No. 118/04, ILDC 880 (KE 2006), 2 March 2006, High Court, para. 32 (simply asserting the customary character of the precautionary principle).

95 Stevens (2002), pp. 14-15; Bodansky (1995), p. 107, fn. 16 on the customary status of the precautionary principle ('I have remained somewhat skeptical'); Tinker (1996), p. 53.

96 C v. Director of Immigration, First instance, HCAL 132/2006, [2008] 2 HKC 165, [2008] HKCFI 109, ILDC 1119 (HK 2008), 18 February 2008, High Court as Court of First Instance, paras. 98, 113-114.

97 See Boyle (2004), p. 63 (writing that international courts 'are representative of the international community', which 'does give them a certain authority to make conclusions about customary law that a national court does not possess').

98 See for instance, Minister of Justice and Constitutional Development and Others v. Southern Africa Litigation Centre and Others, Case No. 867/15, 168 ILR 600, 15 March 2016, South Africa; Supreme Court of Appeal, para. 75 (relying on statements by the ICC: 'The ICC itself has affirmed that the Arrest Warrant case correctly reflects customary international law').
} 
examples are rife. ${ }^{99}$ Domestic courts may not consider international case law as necessarily binding, but clearly they believe that it has persuasive authority, ${ }^{100}$ much like the ICJ has treated relevant ICTY case law in the Bosnia Genocide Case. ${ }^{101}$ However that may be, domestic courts appear to be outsourcing the determination of customary international law norms to international courts, much like they outsource it to the doctrine. When an international court has addressed the matter, they do not normally carry out an extensive law-determination process of their own. ${ }^{102}$ Domestic courts may have little concern that the method of lawdetermination applied by international courts may sometimes be backed by only flimsy evidence. ${ }^{103}$ After all, domestic courts can be expected to defer to international courts on grounds of the latter's superior, expertise-based authority.

It may happen that domestic courts consciously refrain from relying on pertinent international judicial practice regarding the determination of a customary international law norm, without necessarily replacing the international courts' law-

\footnotetext{
99 Assemblies Case, Agě̌ins and ors v. Parliament of Latvia (Saeima), Constitutional Review, Case No. 2006-03-0106, ILDC 1062 (LV 2006), 23 November 2006, Constitutional Court, paras. 28.3-28.4, citing United States Diplomatic and Consular Staff in Tehran, United States v. Iran, Judgment, ICJ Reports 1980, p. 3; ICGJ 124 (ICJ 1980), 24 May 1980; One Third of the National Assembly Deputies, Constitutional Review, Rm-1/00-29, Official Gazette of Slovenia, No. 43/2001, ILDC 402 (SI 2001), 19 April 2001, Constitutional Court; A v. Minister of Immigration and Integration, Highest administrative appeal, Case No. 200408765/1, Jurisprudentie Vreemdelingenrecht (JV) 2005/227, Rechtspraak Vreemdelingenrecht (RV) 2005/12, ILDC 848 (NL 2005), 18 April 2005, Council of State [RvS], para. 2.4.2, relying on Prosecutor v. Tadic, Decision on the Defence Motion on Jurisdiction, Case No. IT-94-1T, 10 August 1995; Public Prosecutor $v$. F, First instance, Criminal procedure, ECLI:NL:RBSGR:2007:BA9575, 09/750001-06, ILDC 797 (NL 2007), 25 June 2007, District Court, para. 66, relying on ICTY case law; Agent Orange Product Liability Litigation, Re, Vietnam Association For Victims Of Agent Orange/Dioxin and ors v. Dow Chemical Company and ors, First Instance, 373 F.Supp.2d 7 (E.D.N.Y. 2005), ILDC 123 (US 2005), 10 March 2005, District Court for the Eastern District of New York [E.D.N.Y.], para. 127, relying on the 'exhaustive analysis' of the ICTY; Helmerich \& Payne International Drilling CO and Helmich \& Payne de Venezuela, CA v. Bolivarian Republic of Venezuela and ors, Trial judgment, 971 F Supp 2d 49 (DDC 2013), ILDC 2148 (US 2013), 20 September 2013, United States; District of Columbia; District Court for the District of Columbia, para. 18; Islamic Republic of Iran and Others v. Hashemi and Estate of the Late Kazemi, 154 ILR 351, 15 August 2012, Canada; Quebec Court of Appeal, paras. 54-55; Estate of Kazemi v. Islamic Republic of Iran and Others, 159 ILR 299, 10 October 2014, Canada; Supreme Court, paras. 38, 153-157; Republic of Ghana v. High Court (Commercial Division) Accra, ex parte Attorney-General (NML Capital Ltd and Republic of Argentina, interested parties, 156 ILR 240, 20 June 2013, Ghana; Supreme Court, paras. 261-262.

100 Canada (Minister of Citizenship and Immigration), League for Human Rights of B'nai Brith Canada (intervening) and ors (intervening) v. Mugesera (Léon) and ors, Appeal to Supreme Court, 2005 SCC 40, paras. $118,126$.

101 Case Concerning Application of the Convention on the Prevention and Punishment of the Crime of Genocide (Bosnia and Herzegovina v. Serbia and Montenegro), Judgment 26 February 2007, ICJ Reports 2007, paras. 223, 344.

102 E.g., Simoncioni and ors v. Germany and President of the Council of Ministers of the Italian Republic (intervening), Constitutional review, Judgment No. 238/2014, ILDC 2237 (IT 2014), 22 October 2014, Italy; Constitutional Court, paras. 3.1-3.4.

103 E.g., on the extension of the principle of uti possidetis: Talmon (2015), pp. 439-440. This is not to say that international courts never carry out an extensive analysis. E.g., Regina v. Gul, EWCA Crim 280, 152 ILR 568, 22 February 2012, England; Court of Appeal, para. 39 (relying on a judgment by the Appeals Chamber of the Special Court of Lebanon which had examined resolutions, treaties, national legislation and national case law to demonstrate state practice in relation to the crime of terrorism).
} 
determination process with their own, however. Three scenarios can be distinguished. First, very exceptionally, domestic courts may take issue with the fact, alluded to above, that international courts often just assert rather than find the law. ${ }^{104}$ A US court of appeals, for instance, refused to heed relevant decisions of the ICJ and the European Court of Human Rights on the ground that these tribunals 'are not empowered to create binding norms of customary international law' and that 'their decisions could not be considered primary sources of international law'. ${ }^{05}$ Such an attitude may at first sight be understandable, but it obviously threatens the uniform application of customary norms and begs the question whether domestic courts are better placed than international courts to determine international law. Second, domestic courts may refrain from applying a customary norm affirmed by an international court when it clashes with domestic constitutional law protections that are considered to prevail over any other legal norms. This attitude appears legitimate insofar as the constitutional law norm is 'consubstantial' with another international norm. ${ }^{106}$ Finally, domestic courts may hold that legal concepts recognised by international tribunals, while entirely valid in inter-state relations, have no relevance for relations under domestic law. ${ }^{107}$ In this vein, the German Constitutional Court held that the concept of 'necessity' could not be invoked as an international law defence to justify the non-performance of contractual obligations owed to private debtors, as these were governed by domestic private law, whereas decisions of international tribunals concerned legal relations under international law. ${ }^{108}$ Somewhat along the same lines, a French appeals court held that it could be inferred from the case law of the ICJ that customary international norms are

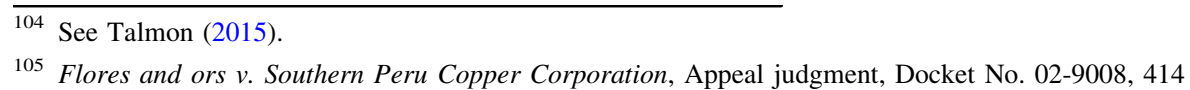
F.3d 233 (2d Cir. 2003), ILDC 303 (US 2003), 29 August 2003, Court of Appeals (2nd Circuit) [2d Cir.], para. 84.

106 See Tzanakopoulos (2014) on the term. Accordingly, from a substantive perspective, the domestic court in fact balances different international law norms instead of giving precedence to domestic law. This has notable relevance for fundamental human rights, which feature in both (domestic?) constitutional and international law instruments, in particular the right to a remedy. Claimants in domestic law proceedings may invoke the right to a remedy so as to restrict the scope of application of international immunities and sanctions.

107 See more generally on domestic courts' views that customary norms only govern inter-state relations: Wouters (2004), p. 34 (referring in particular to the practice of not granting direct effect to international law). See on the law of responsibility Wittich (2013), p. 646 ('While the relevant reference to adjudging the approach of domestic courts towards questions of state responsibility is the 2001 ILC Articles, it is not clear whether these are applicable at all to the relations between states and individuals or non-state entities', although ultimately writing that 'with regard to the content of state responsibility (reparation, that is) the ILC Articles may indeed be viewed as providing the general rules on the matter and can legitimately be employed as a reference for analysing the rules on compensation also in relation between states and individuals').

108 Argentine Necessity Case, $K$ and ors v. Argentina (represented by President Néstor Kirchner), Decision of the Federal Constitutional Court, Order of the Second Senate, 2 BvM 1-5/03, 1, 2/06, vol. 118, 124, 60 NJW (2007), 2610, 138 ILR 1 (2010), ILDC 952 (DE 2007), 8 May 2007, Constitutional Court [BVerfG], paras. 51-66 (adding that an extension of the necessity doctrine was not supported by state practice and opinio juris, and that, given the differentiated treatment given to the concept of necessity in domestic legal systems, it was not a general principle of law). 
applicable to states only. ${ }^{109}$ Since in domestic settings international law is often invoked by or against private actors, such an approach has the potential to seriously restrict the domestic applicability of international law. ${ }^{110}$

Finally, domestic courts may not only refer to international courts, but also to other courts, both from within and outside their own jurisdiction. Rather selfevidently, they tend to defer to higher courts within their national legal system, on the basis that the latter courts have more authority, expertise, and legitimacy. ${ }^{111}$ In some jurisdictions lower courts may even refrain from applying international law, in particular identifying customary international law, when a higher court has not yet addressed the matter. ${ }^{112}$ Such a reserved attitude obviously limits the opportunities for domestic courts' determination of international norms, and their contribution to the content of the sources of international law. Apart from referring to court decisions from within the jurisdiction, domestic courts may also cite relevant decisions of domestic courts from other jurisdictions as evidence of the existence of customary international law norms. ${ }^{113}$ This process has been usefully characterised as 'comparative international law', coming into being on the basis of a transnational judicial dialogue. ${ }^{114}$ While possibly increasing the quality of a court's customary law identification methodology, this however comes with its own risks, such as

\footnotetext{
109 Association France-Palestine Solidarité and Palestine Liberation Organization v. Société Alstom transport SA and ors, Appeal judgment, 11/05331, ILDC 2036 (FR 2013), 22 March 2013, France, para. 121.

110 See also German Constitutional Court, above n. 108, Judge Lübbe-Wolff, dissenting, paras. 89-94.

111 See e.g. Brazil v. Pedro Henrique de Vianna Dos Campos Riscado, Preliminary order on jurisdiction, No. 1981, ILDC 2037 (IT 2012), 13 February 2012, Italy; Supreme Court of Cassation, para. 4; HRH Prince Abdul Aziz bin Fahd bin Abdul Aziz v. Harb, EWCA Civ 481, 168 ILR 656, 13 May 2015, England; Court of Appeal, paras. 36-37; United States v. Dire and ors, Appeal judgment, 680 F3d 446 (4th Cir 2012), ILDC 1985 (US 2012), 23 May 2012, United States; Court of Appeals (4th Circuit), para. 65; United States v. Salad and ors, Decision on motion to dismiss, 908 F Supp 2d 730 (ED Va 2012), ILDC 2027 (US 2012), 30 November 2012, United States; Virginia; District Court for the Eastern District of Virginia, para. 13; Al-Aulaqi v. Obama and ors, Decision on motion to dismiss, 727 F Supp 2d 1 (DDC 2010), ILDC 1636 (US 2010), 7 December 2010, United States; District of Columbia; District Court for the District of Columbia, paras. 73-77.

112 E.g., Ali Shafi and ors v. Palestinian Authority (also known as Palestinian National Authority; also known as Palestinian Interim Self-Government Authority) and Palestine Liberation Organization, Ruling on motion to dismiss, ILDC 1645 (US 2010), 686 F.Supp.2d 23 (D.D.C. 2010), 23 February 2010, District Court for the District of Columbia [D.D.C.], para. 14 (refusing to determine the existence of an international norm against torture by non-state actors in the absence of such a finding by the Supreme Court).

113 Mann v. Republic of Equatorial Guinea, 153 ILR 697, 23 January 2008, Zimbabwe; High Court, para. 711; Tsebe and Society for the Abolition of the Death Penalty in South Africa and Society for the Abolition of the Death Penalty in South Africa (intervening) v. The Minister of Home Affairs and ors, Judgment, 27682/10, ILDC 1782 (ZA 2011), 22 September 2011, South Africa; Gauteng; Johannesburg; South Gauteng High Court, para. 127; FG Hemisphere Associates LLC v. Democratic Republic of the Congo and Others, 142 ILR 216, 10 February 2010, Hong Kong Special Administrative Region; Court of Appeal, para. 71; Estate of Kazemi v. Islamic Republic of Iran and Others, 159 ILR 299, 10 October 2014, Canada; Supreme Court, para. 156; United States v. Hasan and ors, Decision on motion to dismiss, No. 2:10cr56, ILDC 1586 (US 2010), 29 October 2010, United States; Virginia; District Court for the Eastern District of Virginia, para. 95.
}

114 Roberts (2011), p. 81. 
cherry-picking and undue reliance on misguided decisions rendered by courts lacking international law expertise. ${ }^{115}$

\section{Extensive Analysis}

For all the legitimate criticism that can be levelled at courts' international lawdetermination method, one has to concede that exceptionally they do carry out a relatively extensive analysis of relevant state practice for purposes of customary law determination. A few higher court decisions, from the Supreme Courts of Spain, Germany, and Poland, can be singled out in this respect by way of illustration. ${ }^{116}$ Such decisions may be commended for aligning with the two-element approach to customary law identification. As this article is primarily concerned with systematization, however, it is not our ambition to develop a best practices-based normative blueprint of how to properly identify customary international law in concreto. Nor have we reviewed whether the extensive analysis and the conclusions reached in the specific cases were sound. The examples given here are only meant to show that domestic courts do sometimes engage in extensive analysis. It can obviously not be excluded that even an extensive analysis may lack rigor.

In the Guatemala Genocide case, the Spanish Constitutional Court analysed in detail abundant foreign legislation before reaching the conclusion that the principle of universal jurisdiction was not subject to the existence of a 'connection' with national interests. ${ }^{117}$ In the Yemeni Citizens Extradition case, the German Constitutional Court clearly set out its methodology of ascertaining customary international law - the two-elements approach — and subsequently engaged in detail with foreign courts' case law in order to find an answer to the question whether the fact that a prosecuted person had been lured out of his or her state of origin is an obstacle precluding extradition. ${ }^{118}$ In the Natoniewski case, the Polish Supreme Court carried out a thorough analysis of national legislation and case law (i.e., actual

\footnotetext{
115 Ryngaert (2017).

116 ILC (2014), the ILC Special Rapporteur considered the judgments of a state's highest courts to naturally carry more weight for purposes of the formation of customary international law. Note, however, that lower courts may sometimes reach bolder decisions, and may be willing to develop international law further than more inherently conservative higher courts are willing to do. See Stirling-Zanda (2004) pp. 4, 7. See for an example Mabibi-Ma-Kibebi v. The Democratic Republic of Congo, Fortis Bank S.A., The State of Belgium and the French Community, Appeal judgment, Case No. 2008/AR/2441, ILDC 1623 (BE 2010), 26 April 2010 (splitting the burden of proof between the creditor and the state in respect of foreign States' immunity from execution as far as embassy bank accounts are concerned), overruled by Court of Cassation (Court of Cassation 6 June 2014, C.10.0482.F/2.).

117 Guatemala Genocide Case, Menchú Tum (Rigoberta) and ors v. Two Guatemalan Government Officials and Six members of the Guatemalan Military, Constitutional Appeal, Case No. 237/2005, ILDC 137 (ES 2005), 26 September 2005, Constitutional Court, para. 6.

118 Yemeni citizens extradition case, Anonymous, Individual constitutional complaint, 2 BvR 1506/03, BVerfGE 109, 13, NJW 2004, 141, ILDC 10 (DE 2003), 5 November 2003, Constitutional Court [BVerfG], para. 53. In light of the heterogeneity of the various courts' case law, the Court concluded that no such norm existed. See for a general discussion of the German Constitutional Court's approach to the ascertainment of customary international law: Paulus (2013), pp. 262-263 (characterising the Court's engagement with foreign court practice as part of the 'modern approach' to custom).
} 
state practice), treaties, case law of the ICJ and the European Court of Human Rights, and doctrine, before concluding that there is no customary law-based exception to state immunity for grave violations of human rights. ${ }^{119}$

\section{Conclusion}

The analysis in this article has demonstrated that, similar to the ICJ, domestic courts do not normally identify norms of customary international law on the basis of the textbook method of ascertaining a general practice accepted as law. ${ }^{120}$ Rather, they tend to outsource the determination of custom to treaties, non-binding documents, doctrine or international judicial practice. Sometimes, it appears that domestic courts simply assert, without citing persuasive practice authority, the existence of a customary norm. Arguably, domestic courts feel more comfortable referring to (more or less) authoritative international written sources. They may be forgiven for doing so, as they are not experts in international law. Indeed, for domestic courts it may be particularly challenging to gather and assess relevant state practice, and identify opinio juris. ${ }^{121}$

At the same time, by using 'shortcuts', domestic courts may want to signal their impartiality and legitimacy in determining customary international law, for much the same reason as the ICJ uses such shortcuts. As Niels Petersen has observed, how exactly a law-applying agency-in his study the ICJ-analyses state practice is often difficult to observe and will always be selective, or at least carry a whiff of selectivity. ${ }^{122}$ Thus, they may cite international treaties with a view to more strongly anchor an identified customary norm in the consent of states, and on that basis, preempt accusations that they favour one party over another. ${ }^{123}$ From this perspective, a painstaking analysis of state practice and opinio juris may backfire politically. That being said, such political dynamics may be rather particular to the ICJ. As the Court's jurisdiction is not compulsory, states may withdraw their acceptance of jurisdiction in case the Court is seen as taking decisions that are insufficiently rooted in state consent. This risk of state withdrawal is obviously not present before domestic courts. Still, by taking decisions that are insufficiently attuned to the interests of the community of states, domestic courts risk legislative intervention by

\footnotetext{
119 Natoniewski v. Germany, Cassation complaint, Case No. IV CSK 465/09, ILDC 1996 (PL 2010), (2010) 30 Polish YB International Law 299, 29 October 2010, Poland; Supreme Court, paras. 32-36. See also the same court, also concerning the customary law of state immunity, in Winicjusz $N$ v. Federal Republic of Germany, Appeal in cassation, SN IV CSK 465/09, Orzecznictwo Sądu Najwyż szego Izba Cywilna 2011/2/22, ILDC 1769 (PL 2010), 29 October 2010, Poland, paras. 26, 32-36.

120 See also e.g. Lijnzaad (2016), p. 130; Szewczyk (2014), p. 1133; Gutierrez and Gulati (2017), p. 273 on US case law.

121 See also Sandholz (2015), p. 613 (submitting that, for that reason, international instruments function as guidance for domestic courts).

122 Petersen (2017), p. 377.

123 Ibid., p. 369.
} 
the forum state, which may clip courts' customary law-finding wings. ${ }^{124}$ It remains that from a doctrinal perspective, a serious legal analysis of all available materials is called for. Ultimately, courts, and especially domestic courts, which function in a state governed by the rule of law, are supposed to identify and apply the law, regardless of the political ramifications of their decisions. Therefore, a rigorous application of the two-elements approach to customary law identification by domestic courts is called for. How such rigor is to be achieved has not been the subject of this article. In fact, it is the subject of a large-scale, on-going ILC study, which has triggered intensive academic activity on customary law-identification methods. ${ }^{125}$ In any event, in order to preserve the unity of customary law formation methodology, it is posited that no distinction should be drawn between law-applying agencies: thus, both international and domestic courts should use the same methodology.

Open Access This article is distributed under the terms of the Creative Commons Attribution 4.0 International License (http://creativecommons.org/licenses/by/4.0/), which permits unrestricted use, distribution, and reproduction in any medium, provided you give appropriate credit to the original author(s) and the source, provide a link to the Creative Commons license, and indicate if changes were made.

\section{References}

Arajärvi N (2017) From the 'demands of humanity': the formulation of opinio juris in decisions international criminal tribunals and the need for a renewed emphasis on state practice. In: Lepard B (ed) Reexamining customary international law. Cambridge University Press, New York, pp 189-232

Bodansky M (1995) Customary (and not so customary) international environmental law. Indiana J Glob Legal Stud 3(1):107-120

Boyle A (2004) International law before national courts: some problems from a common law perspective. Non State Actors Int Law 4(1):59-64

Choi SJ, Gulati M (2016) Customary international law, how do courts do it? In: Bradley C (ed) Custom's future international law in a changing world. Cambridge University Press, New York, pp 117-147

Corbin J, Strauss A (1998) Basics of qualitative research: techniques and procedures for developing grounded theory, 2nd edn. Sage Publications Inc, Thousand Oaks

Corbin J, Strauss A (2015) Basics of qualitative research: techniques and procedures for developing grounded theory, 4th edn. Sage Publications Inc, Los Angeles

\footnotetext{
124 E.g., the new articles L. 111-1-1 to L. 111-1-3 of the French Code des procédures civiles d'exécution (amended in 2016), which severely limit the possibility of ordering enforcement measures against foreign states. The articles were inserted after domestic courts, citing applicable customary international law, had refused to uphold foreign states' immunity from execution. In 2015, for instance, the French Court of Cassation had decided that only an express waiver of immunity rather than a specific one was required under customary law. Cass. Fr., civ. 1ere, 13 May 2015, $\mathrm{n}^{\circ}$ 13-17.751. The statutory amendment was swiftly dubbed the 'Putin amendment', as it was arguably informed by the French Government's desire to prevent a barrage of enforcement proceedings against the Russian Federation, which would compromise the diplomatic relations between France and Russia. Cf., " "L'amendement Poutine" adopté dans la loi Sapin 2', Le Figaro, 16 June 2016.

125 See for the latest text adopted by the ILC Drafting Committee: 'Identification of customary international law', A/CN.4/L.872, 30 May 2016, http://legal.un.org/docs/?symbol=A/CN.4/L.872 (accessed 20 January 2018). See for academic commentary Yee (2015), pp. 375-398; see the special issue on customary international law in the Chinese Journal of International Law, vol. 15, issue 1, pp. 1-216 (2016), see e.g. Wood (2016), pp. 3-15; Scobbie and Droubi (2018).
} 
Crawford J (2012) Brownlie's principles of public international law, 8th edn. Oxford University Press, Oxford

D'Aspremont J (2011) Formalism and the sources of international law. Oxford University Press, Oxford

Gutierrez N, Gulati M (2017) Custom in our courts: reconciling theory with reality in the debate about Erie Railroad and customary international law. Duke J Comp Int Law 27:243-290

ILC Special Rapporteur (2013a) First report on formation and evidence of customary international law. UN Doc A/CN.4/663

ILC Special Rapporteur (2013b) Second report on the immunity of State officials from foreign criminal jurisdiction. UN Doc A/CN.4/661

ILC Special Rapporteur (2014) Second report on identification of customary international law. UN Doc A/CN.4/672

Kirby M (2008) Transnational judicial dialogue, internationalisation of law and Australian judges. Melbourne J Int Law 9(1):171-189

Lijnzaad L (2016) Customary international law before Dutch courts: the Nyugat II case and beyond. In: Lijnzaad L, Council of Europe (eds) The judge and international custom. Brill Nijhoff, Dordrecht, pp 121-134

Malterud K et al (2016) Sample size in qualitative interview studies: guided by information power. Qual Health Res 26:1753-1760

Mendelson M (2004) The effect of customary international law on domestic law: an overview. Non State Actors Int Law 4(1):75-85

Moremen PM (2006) National court decisions as state practice: a transnational judicial dialogue? N C J Int Law Commer Regul 32(2):259-310

Oderkerk O (2015) The need for a methodological framework for comparative legal research: sense and nonsense of 'methodological pluralism' in comparative law. Rabels Zeitschrift für ausländisches und internationales Privatrecht 79(3):589-623

Olleson S (2013) Internationally wrongful acts in the domestic courts: the contribution of domestic courts to the development of customary international law relating to the engagement of international responsibility. Leiden J Int Law 26(3):615-642

Paulus A (2013) The judge and international custom. Law Pract Int Courts Tribunals 12(2):253-265

Pavoni R (2007) La jurisprudence italienne sur l'immunité des États dans les différends en matière de travail: tendances récentes à la lumière de la convention des Nations Unies. Annuaire français de droit international 53:211-223

Petersen N (2017) The International court of justice and the judicial politics of identifying customary international law. Eur J Int Law 28(2):357-385

Reinisch A, Bachmayer P (2012) The identification of customary international law by Austrian courts. Austrian Rev Int Eur Law 17:1-48

Roberts A (2011) Comparative international law? The role of national courts in creating and enforcing international law. Int Comp Law Q 60(1):57-92

Ryngaert C (2017) Sources of international law in domestic law-relationship between international and municipal law sources. In: d'Aspremont J, Besson S, Knuchel S (eds) The Oxford handbook on the sources of international law. Oxford University Press, Oxford, pp 1137-1156

Sandholz W (2015) How domestic courts use international law. Fordham Int Law J 38(2):595-637

Scobbie I, Droubi S (eds) (2018) Non-state actors and the formation of customary international law. Melland Schill Perspectives in International Law. Manchester University Press, Manchester (forthcoming)

Stevens M (2002) The precautionary principle in the international arena. Sustain Dev Law Policy 2(2): $13-22$

Stirling-Zanda S (2004) The determination of customary international law in European courts (France, Germany, Italy, The Netherlands, Spain, Switzerland). Non State Actors Int Law 4(1):3-24

Stirn B (2013) La place de la coutume internationale en droit public français. Law Pract Int Courts Tribunals 12(2):267-271

Szewczyk B (2014) Customary international law and statutory interpretation: an empirical analysis of Federal Court decisions. Geo Wash Int Law Rev 82(4):1118-1193

Talmon S (2015) Determining customary international law: the ICJ's methodology between induction, deduction and assertion. Eur J Int Law 26(2):417-443

Tinker C (1996) State responsibility and the precautionary principle. In: Freestone D, Hey E (eds) The precautionary principle and international law: the challenge of implementation. Kluwer, The Hague, pp 53-73 
Tomka P (2016) Customary international law in the jurisprudence of the world court: the increasing relevance of codification. In: Lijnzaad L, Council of Europe (eds) The judge and international custom. Brill Nijhoff, Dordrecht, pp 1-24

Tzanakopoulos A (2014) Judicial dialogue as a means of interpretation. In: Aust HP, Nolte G (eds) The interpretation of law by domestic courts: uniformity, diversity and convergence. Oxford University Press, Oxford, pp 72-95

Wittich S (2013) Domestic courts and the content and implementation of state responsibility. Leiden J Int Law 26(3):643-665

Wood M (2016) The present position within the ILC on the topic 'Identification of customary international law': in partial response to Sienho Yee, Report on the ILC Project on 'Identification of Customary International Law'. Chin J Int Law 15(1):3-15

Wouters J (2004) Customary international law before national courts: some reflections from a continental European perspective. Non State Actors Int Law 4(1):25-38

Yee S (2015) Report on the ILC Project on 'Identification of Customary International Law'. Chin J Int Law 14(2):375-398

Yee S (2016) A reply to Sir Michael Wood's response to AALCOIEG's work and my report on the ILC Project on Identification of Customary International Law. Chin J Int Law 15(1):33-40 